\title{
INSULIN-RESISTANT DIABETES ASSOCIATED WITH INCREASED ENDOGENOUS PLASMA INSULIN FOLLOWED BY COMPLETE REMISSION
}

\author{
By JAMES B. FIELD, PHYLLIS JOHNSON AND BETTY HERRING \\ (From the Clinical Endocrinology Branch, National Institute of Arthritis and Metabolic \\ Diseases, Bethesda, Md.)
}

(Submitted for publication March 1, 1961 ; accepted April 21, 1961)

Insulin unresponsiveness may be associated with a multitude of conditions and reflect diverse etiologies (1). In most cases of chronic insulin resistance it has been possible to demonstrate insulin antagonists in the plasma which have many of the characteristics of antibodies $(2-4)$. The resistance to insulin has usually been attributed to these antibodies, but several cases of insulin resistance associated with increased amounts of insulin in the plasma have been reported (5-8). In these cases tissue unresponsiveness was postulated as the cause for the resistance. In all of these cases circulating insulin could be demonstrated only at a time when the patients were receiving large doses of exogenous insulin, and therefore the insulin in the plasma probably represented injected insulin. We recently have had occasion to study a patient with severe insulin resistance whose plasma contained large amounts of insulin 3 months after her last known injection. Over the ensuing 18 months she had a gradual but complete remission of both diabetes and insulin unresponsiveness. The purpose of this paper is to report studies on this case which indicate that the insulin-like activity in her plasma did, in fact, represent endogenous insulin and that the cause for her insulin resistance was probably due to decreased tissue responsiveness to the hormone. The explanation for her remission is unknown, although there are occasional reports in the literature of spontaneous remission in severe diabetics (9). As far as we know this is the first reported case of insulin-resistant diabetes associated with greatly increased levels of endogenous insulin.

\section{METHODS}

The rat hemidiaphragm studies were done as follows. Fed rats weighing between 120 and $170 \mathrm{~g}$ were killed by a blow on the head; the diaphragms were removed as rapidly and with as little trauma as possible. Each hemi- diaphragm was trimmed, blotted, weighed on a torsion balance and then put into a flask holding $2 \mathrm{ml}$ of incubation medium which contained $0.5 \mathrm{ml}$ of $1,000 \mathrm{mg}$ per 100 $\mathrm{ml}$ glucose in Krebs-Ringer bicarbonate buffer ( $\mathrm{pH} 7.4$ ), variable amounts up to $1 \mathrm{ml}$ of dialyzed plasma to be tested, and enough Krebs-Ringer bicarbonate buffer to make the final volume $2 \mathrm{ml}$. When standard insulin solutions were tested, appropriate dilutions of a stock insulin solution (40 $\mathrm{U}$ per $\mathrm{ml}$ ) were made with Krebs-Ringer bicarbonate buffer. Control flasks with the appropriate amount of plasma or buffer but without tissue were included in each experiment for the determination of the initial glucose concentration. The flasks were gassed with 95 per cent $\mathrm{O}_{2}$ and 5 per cent $\mathrm{CO}_{2}$ and incubated for 90 minutes at $37^{\circ} \mathrm{C}$ on a Dubnoff metabolic shaker. Glucose concentrations were measured on duplicate $0.5 \mathrm{ml}$ aliquots of the incubation medium with glucose oxidase (Glucostat, Worthington Biochemical Corp.). The difference between the initial and final glucose concentration was calculated and the results expressed as milligram of glucose uptake per gram of muscle. In each experiment the test samples of plasma and insulin standards were assayed in triplicate. Glycogen deposition in the rat diaphragm at the end of the incubation period was measured by the anthrone method (10).

Protein fractionation of plasma was done by starch block electrophoresis and veronal buffer $(\mathrm{pH} 8.6)$, ionic strength 0.05 (11). After electrophoresis the block was cut into $1 \mathrm{~cm}$ segments and the protein recovered by centrifugation. Protein concentration was determined either by ultraviolet absorption at $284 \mathrm{~m} \mu$ in the Beckman DU spectrophotometer or by the modified method of Folin (12). Protein solutions of two adjacent segments were combined, dialyzed against distilled water and then lyophilized. The resulting protein dissolved in KrebsRinger bicarbonate buffer was assayed in the rat hemidiaphragm system for insulin-like activity. Equal volumes of the various fractions were tested. In one experiment $20 \mu \mathrm{U}$ of insulin- $\mathrm{I}^{131}$ obtained from Abbott Laboratories was added to $1 \mathrm{ml}$ of plasma prior to electrophoresis. In this experiment the plasma fractions were also assayed for radioactivity in a well-type scintillation counter and counted to an accuracy of 5 per cent.

The rate of disappearance of insulin- $\mathrm{I}^{131}$ was measured as follows: $40 \mu \mathrm{c}$ of insulin- $\mathrm{I}^{131}$ (Abbott Labs.), representing $0.25 \mathrm{U}$ of insulin, was rapidly injected intravenously. Blood samples were obtained just before and at $2.5,15,30,60,120,180$, and 240 minutes and 24,48 , 
and 72 hours after the injection. Thyroid utilization of iodide was blocked with methimazole (Tapazole). The trichloroacetic acid (TCA)-precipitable radioactivity was determined according to the method of Mortimore, Tietze and Stetten (13). Since no attempt was made to distinguish denatured TCA-precipitable insulin- $\mathrm{I}^{131}$ from undamaged insulin- $\mathrm{I}^{131}$, the latter part of the disappearance curve may be falsely prolonged (14).

Adipose tissue from the buttock was obtained by biopsy under local anesthesia. The tissue was immediately sliced with a Stadie-Riggs microtome, blotted, weighed and then each slice put into a flask containing $2 \mathrm{ml}$ of KrebsRinger bicarbonate buffer and $250 \mathrm{mg}$ per $100 \mathrm{ml}$ glucose with or without insulin. When insulin was present its final concentration was $0.1,0.5$, or $1 \mathrm{U}$ per $\mathrm{ml}$. In the usual experiment, incubations were done in quadruplicate. Chilling was avoided and the incubation conditions were similar to those for rat diaphragms. The glucose uptake per gram of tissue was calculated as for the rat diaphragm studies. It is realized that these amounts of insulin are large and much greater than those detected by rat epididymal fat pad (15). In preliminary experiments with normal human adipose slices it was found that $0.1 \mathrm{U}$ per $\mathrm{ml}$ was the smallest insulin concentration giving a consistent effect. The trauma to the tissue during the biopsy and subsequent slicing may be responsible for this decreased sensitivity. The effect of insulin on glucose uptake by leukocytes was measured by the procedure of Weinberg (16). The amount of insulin, $0.6 \mathrm{U}$ per $\mathrm{ml}$, used in these studies was not physiologic but was necessary for the demonstration of an insulin effect. The study of the in vivo oxidation of glucose-1$\mathrm{C}^{14}$ to $\mathrm{C}^{14} \mathrm{O}_{2}$ was kindly performed by Dr. Stanton Segal of this Institute (17).

Insulin antibody plasma was obtained from a patient with chronic insulin resistance; $0.1 \mathrm{ml}$ of this plasma was capable of abolishing the effect of $2 \times 10^{-3} \mathrm{U}$ of insulin in the rat diaphragm test system (18). Intravenous insulin tolerance tests were performed with glucagon-free insulin kindly supplied by Eli Lilly and Co.

\section{CASE REPORT ${ }^{1}$}

This 18 year old Negro female had enjoyed excellent health until age 15 when she noted the onset of tiredness, weight loss, polyuria, polydipsia and polyphagia. A diagnosis of diabetes mellitus was made on the basis of hyperglycemia and glycosuria and she was admitted to the West Jersey Hospital in Camden, N. J. She was placed on a diabetic diet and insulin, but despite increasing the dosage to $50 \mathrm{U}$ per day she continued to have constant glycosuria and acetonuria, although her symptoms diminished. She was discharged from the hospital, taking $50 \mathrm{U}$ $\mathrm{NPH}$ insulin each morning and a diabetic diet. Because of persistent hyperglycemia, glycosuria and acetonuria,

1 We are indebted to Drs. Bruce Carruthers and Stanley Spoont, University of Pennsylvania Hospital, for referral of this patient and the summary of her hospitalization at that hospital. her insulin dosage was gradually increased over the next 6 months until she was receiving $600 \mathrm{U}$ per day in divided doses. During this period she was asymptomatic, had regained some weight and had never experienced any insulin reactions. She was then referred to the diabetic clinic of the University of Pennsylvania Hospital. Over the next 3 months the insulin dosage was increased further without any apparent change in her glycosuria. Fasting blood sugars were frequently over $300 \mathrm{mg}$ per $100 \mathrm{ml}$. She was admitted to the University of Pennsylvania Hospital in October 1958 for evaluation. Her system review was negative except for increasing pigmentation of the skin without light sensitivity, of 1 year's duration, and amenorrhea for the same period.

The past history and family history were unremarkable except that her paternal grandmother had diabetes adequately controlled with tolbutamide. Physical examination was normal except for acanthosis nigricans (confirmed by skin biopsy), carotenemia and small, tender subcutaneous lumps in the thighs at the sites of insulin injections. Initial laboratory data included: hemoglobin $16.1 \mathrm{~g}$; white count 3,900 cells per $\mathrm{mm}^{3}$ with 46 per cent neutrophils, 2 per cent eosinophils, 4 per cent monocytes and 48 per cent lymphocytes; blood-urea-nitrogen $8 \mathrm{mg}$ per $100 \mathrm{ml}$; fasting blood sugar $186 \mathrm{mg}$ per $100 \mathrm{ml}$ and 2 hour postprandial blood sugar 351 ; serum proteins 6.8 $\mathrm{g}$ with $3.1 \mathrm{~g}$ albumin and $3.7 \mathrm{~g}$ globulin; cholesterol 177 $\mathrm{mg}$ per $100 \mathrm{ml}$; negative urinalysis except for $4+$ glycosuria and acetonuria; normal electrolytes and $\mathrm{CO}_{2}$ values; serum carotene $107 \mu \mathrm{g}$ per $100 \mathrm{ml}$.

Attempts were made to control the diabetes by increasing her daily insulin dosage but without much success. She continued to have constant glycosuria and acetonuria. Once her urine was negative for sugar and her blood sugar was $90 \mathrm{mg}$ per $100 \mathrm{ml}$ after an 18 hour fast and $6,000 \mathrm{U}$ insulin. Cortisol therapy was not beneficial, and while on steroids, her insulin dosage was increased to $14,000 \mathrm{U}$ of regular insulin per day. Her 24-hour urinary excretion of glucose was $292 \mathrm{~g}$. Steroids were discontinued and metahexanamide (Metahexamide) therapy (300 mg per day) was instituted. She continued to have hyperglycemia on this therapy and insulin was increased to $38,000 \mathrm{U}$ per day. Despite this amount of insulin her 24 hour urinary glucose output ranged from 109 to $190 \mathrm{~g}$. At this point insulin and metahexanamide therapy was discontinued and she was treated with $200 \mathrm{mg}$ phenethylbiguanide (DBI) daily. Urinary glucose content increased to approximately $245 \mathrm{~g}$ per 24 hours, and the addition of insulin had no effect. At no time during her hospitalization was there any evidence of hypoglycemia or definite acidosis, although on one occasion a $\mathrm{CO}_{2}$ of $16 \mathrm{mEq}$ per $\mathrm{L}$ and a positive undiluted plasma acetone test was obtained. These quickly returned to normal without any special therapy.

Immunologic studies indicated a negative skin test to Lente insulin, regular beef insulin and pork insulin. A1though she had reported tender lumps at the site of insulin injections, there had never been any generalized allergic manifestations. Antibodies to insulin could not be demonstrated by passive transfer. Intravenous insulin 
injections of $100 \mathrm{U}$ of either beef or pork insulin caused no significant decrease in the blood sugar.

Since her hyperglycemia, glycosuria and acetonuria were unaffected by insulin, she was treated by diet alone and 1 month later was transferred to the Clinical Center, National Institutes of Health, for further studies. She felt well except for some dryness of the mouth and excessive hunger. Her physical examination showed no change when compared with that of her admission to the University of Pennsylvania Hospital. Her initial laboratory workup included a normal urinalysis except for a $2+$ urine sugar and positive acetonuria; hematocrit 43 per cent; WBC 2,900 per $\mathrm{mm}^{3}$ with 40 per cent mature polymorphonuclear leukocytes, 50 per cent lymphocytes, 9 per cent monocytes and 1 per cent eosinophils. Sedimentation rate was $15 \mathrm{~mm}$ per hour; fasting blood sugar $252 \mathrm{mg}$ per $100 \mathrm{ml}$; total cholesterol $200 \mathrm{mg}$ per $100 \mathrm{ml}$; $\mathrm{CO}_{2} 26$ $\mathrm{mEq}$ per L; serum sodium, chloride and potassium 141, 104 , and $4.5 \mathrm{mEq}$ per $\mathrm{L}$, respectively; unesterified fatty acids $1.47 \mathrm{mEq}$ per $\mathrm{L}$; total protein $6.7 \mathrm{~g}$ with $3.3 \mathrm{~g}$ albumin and $3.4 \mathrm{~g}$ globulin; serum electrophoresis indicated albumin $2.86 \mathrm{~g}, \alpha_{1}$-globulin $0.33 \mathrm{~g}, \alpha_{2}$-globulin $0.52 \mathrm{~g}$, $\beta$-globulin $0.98 \mathrm{~g}$ and $\gamma$-globulin $1.82 \mathrm{~g}$; transaminase 30 ; alkaline phosphatase 1.8 Bodansky units; 2 per cent retention of sulfobromophthalein at the end of 45 minutes; cephalin flocculation $1+$ in 24 hours and $2+$ in 48 hours; basal metabolic rate -8 per cent; protein-bound iodine 5.0 $\mu \mathrm{g}$ per $100 \mathrm{ml}$; plasma cortisol $16 \mu \mathrm{g}$ per $100 \mathrm{ml}$; 24hour urinary 17-hydroxycorticosteroids and 17-ketosteroids 4.5 and $3.5 \mathrm{mg}$, respectively.

She was asymptomatic without insulin therapy despite 24-hour urine glucose excretion of up to $332 \mathrm{~g}$ while taking a 3,175 caloric diet containing $300 \mathrm{~g}$ carbohydrate. When allowed to eat ad libitum she consumed 6,000 calories per day and her urinary glucose excretion rose to approximately $600 \mathrm{~g}$ per 24 hours. Acetonuria was present constantly and 24-hour urine samples contained as much as $20 \mathrm{~g}$ of ketone bodies. Fasting blood sugars ranged from 155 to $285 \mathrm{mg}$ per $100 \mathrm{ml}$ and postprandial sugars were as high as 519 . Despite this glycosuria and acetonuria her weight actually increased from $42.3 \mathrm{~kg}$ at the time of admission to $45.6 \mathrm{~kg}$ at the time the initial studies, which serve as the basis for this report, were undertaken.

Two months after her admission she developed mild indigestion, heartburn, anorexia, increased thirst, nocturia and nausea, and she lost $1.1 \mathrm{~kg}$ of weight over a 2-day period. Her fasting blood sugar was found to be $420 \mathrm{mg}$ per $100 \mathrm{ml}$ and her $\mathrm{CO}_{2} 17 \mathrm{mEq}$ per L. Her plasma acetone was positive in a $1: 3$ dilution whereas previously it had been negative. Sodium was 128 , chloride 100 , and potassium $5.1 \mathrm{mEq}$ per L. Physical condition was unchanged except for increased respiratory rate later accompanied by typical Kussmaul respiration and a tender liver edge on deep inspiration. Dehydration was not striking. Since she had not received insulin for over 3 months, treatment was started with amounts of insulin that would be considered small in comparison with her previously tolerated doses. Over the next several hours she received $300 \mathrm{U}$ regular insulin i.v. and fluid therapy consisting of $0.17 \mathrm{M}$ lactate and $0.5 \mathrm{~N}$ salinc plus $40 \mathrm{mEq} \mathrm{KCl}$. She ate a regular diet. Several hours later her blood sugar had risen to $590 \mathrm{mg}$ per $100 \mathrm{ml}$ and $\mathrm{C}($ ), was $16 \mathrm{mEq}$ per $\mathrm{L}$ with no change in her clinical status. She was given another $825 \mathrm{U}$ regular insulin i.v. over the ensuing 4 hours with a resultant fall in blood sugar to $300 \mathrm{mg}$ per $100 \mathrm{ml}$ but her $\mathrm{CO}_{2}$ had also declined to $14 \mathrm{mEq}$ per $\mathrm{L}$. Because of the continuing decline in $\mathrm{CO}_{2}$ she was given an injection of $1,000 \mathrm{U}$ regular insulin i.v. and fructose was added to the intravenous fluid therapy. Fifteen minutes later she developed fever to $104^{\circ} \mathrm{F}$, shaking chills, and generalized urticaria. The various intravenous fluids being administered at the time were tested and were pyrogenfree. Since this might be an allergic reaction to insulin, she was given $100 \mathrm{mg}$ cortisol hemisuccinate i.v. and $1,000 \mathrm{U}$ regular insulin i.m. every hour for the next 4 hours. At the end of this time her blood sugar was 450 $\mathrm{mg}$ per $100 \mathrm{ml}$ and $\mathrm{CO}_{2}$ had decreased to $12 \mathrm{mEq}$ per $\mathrm{L}$. Fever and chills did not recur and urticaria disappeared. In view of the further deterioration of the blood sugar and $\mathrm{CO}_{2}$, she was given $12,000 \mathrm{U}$ of regular insulin in saline i.v. over the next 6 hours. At the end of this she felt better and her $\mathrm{CO}_{2}$, was found to be $15 \mathrm{mEq}$ per $\mathrm{L}$ and blood sugar $320 \mathrm{mg}$ per $100 \mathrm{ml}$. During the next 12 hours she continued to receive intravenous fructose, lactate and saline as well as $20 \mathrm{mg}$ prednisone and 3,000 $\mathrm{U}$ insulin. She was then completely asymptomatic, with a blood sugar of $207 \mathrm{mg}$ per $100 \mathrm{ml}$ and a $\mathrm{CO}_{2}$ of $24 \mathrm{mEq}$ per L.

For the next 2 days she received $1,000 \mathrm{U}$ regular insulin i.m. per day and $40 \mathrm{mg}$ prednisone. Intravenous fluids were discontinued and she consumed her usual diet. Although she again had hyperglycemia, her $\mathrm{CO}_{2}$ was normal. The next day she again had anorexia and nausea, and $\mathrm{CO}_{2}$ was $14 \mathrm{mEq}$ per $\mathrm{L}$, with a blood sugar of $365 \mathrm{mg}$ per $100 \mathrm{ml}$. Plasma acetone was positive in a dilution of $1: 8$ whereas it had been negative the previous day. An insulin-I ${ }^{131}$ half-time disappearance of 2 hours had been found the previous day as compared with one of 10 hours 1 week before. Because of this change in insulin disappearance rate and because the patient was still on steroids, insulin therapy was begun with small doses. She was given $25 \mathrm{U}$ regular insulin i.v.; 30 minutes later her blood sugar was $375 \mathrm{mg}$ per $100 \mathrm{ml}$ as compared with 365 before the insulin. Intravenous lactate, fructose and saline were again administered as well as an infusion of $1,000 \mathrm{U}$ insulin per hour. Later in the day there was some clinical improvement and $\mathrm{CO}_{2}$ had risen to $17 \mathrm{mEq}$ per $\mathrm{L}$ although her blood sugar was $420 \mathrm{mg}$ per $100 \mathrm{ml}$. Plasma acetone was still positive in a dilution of $1: 4$. She was greatly improved clinically the next morning; $\mathrm{CO}_{2}$ was $23 \mathrm{mEq}$ per $\mathrm{L}$ and blood sugar was $115 \mathrm{mg}$ per $100 \mathrm{ml}$.

Because of the recurrent acidosis it was decided to decrease the prednisone and attempt to maintain her on $2,000 \mathrm{U}$ insulin per day. Several days later $\mathrm{CO}_{2}$ was 14 $\mathrm{mEq}$ per $\mathrm{L}$ and fasting blood sugar $183 \mathrm{mg}$ per $100 \mathrm{ml}$. 
TABLE I

Blood ylucose response after intravenous insulin

\begin{tabular}{|c|c|c|c|c|c|c|c|}
\hline \multirow[b]{2}{*}{ Date } & \multirow[b]{2}{*}{ Insulin } & \multicolumn{6}{|c|}{$\begin{array}{l}\text { Blood glucose } \\
\text { minutes }\end{array}$} \\
\hline & & 0 & 15 & 30 & 45 & 60 & 90 \\
\hline & $U$ & \multicolumn{6}{|c|}{$\mathrm{mg}$ per $100 \mathrm{ml}$} \\
\hline Sept. 1959 & 10 & 150 & 145 & 140 & & 124 & 114 \\
\hline Sept. 1959 & 200 & 186 & 141 & 139 & & 135 & 120 \\
\hline Sept. 1960 & 6 & 54 & 17 & 22 & 31 & 32 & 46 \\
\hline
\end{tabular}

Since she was asymptomatic and it was not clear whether fluid therapy or massive doses of insulin were responsible for her improvement during her two previous episodes of acidosis, it was decided to try i.v. fructose and saline without insulin. Although there was a slight decrease in the plasma free fatty acids ${ }^{2}$ during the infusion, the blood sugar rose to $519 \mathrm{mg}$ per $100 \mathrm{ml}$. The next morning her fasting blood sugar was $267 \mathrm{mg}$ per $100 \mathrm{ml}$ and $\mathrm{CO}_{2}$ $15 \mathrm{mEq}$ per $\mathrm{L}$. Intravenuos $0.17 \mathrm{M}$ lactate therapy, again without insulin, was administered. This therapy produced no change in plasma free fatty acids, although there was a slight fall in the blood sugar. Over the next 4 days $\mathrm{CO}_{2}$ gradually rose to $28 \mathrm{mEq}$ per $\mathrm{L}$ despite the fact that she was given no insulin therapy nor further intravenous fluid. The massive doses of insulin given during her first two episodes of acidosis were of questionable benefit. No apparent cause for these three episodes of acidosis could be found, and large amounts of insulin were present in her plasma just before insulin treatment of the first episode was initiated. She had no further episodes of acidosis and remained asymptomatic with no insulin therapy. She continued to have constant glycosuria and acetonuria. At time of discharge, in May 1959, she weighed $49.7 \mathrm{~kg}$ and was advised to take no insulin but to follow a 2,100 calorie diabetic diet $\left(\mathrm{C}_{2000} \mathrm{P}_{100} \mathrm{~F}_{100}\right)$.

She was readmitted to the Clinical Center 2 months later for subcutaneous fat biopsy to assess the insulin responsiveness of this tissue. While at home she was asymptomatic and her glycosuria, although still present, was diminished. Her weight on admission was $55.5 \mathrm{~kg}$ and the physical examination showed no change from her previous admission. Fasting blood sugars ranged from 150 to $244 \mathrm{mg}$ per $100 \mathrm{ml}$ and 4 p.m. blood sugars as high as $700 \mathrm{mg}$ per $100 \mathrm{ml}$ were recorded. Table I summarizes the response of her blood sugar to various amounts of glucagon-free insulin given intravenously during this admission and 1 year later when both the diabetes and insulin resistance were in complete remission. The results in September 1959 confirmed the fact that she was still insulin-resistant at that time. Whereas during her previous admission she had excreted up to $332 \mathrm{~g}$ of glucose per 24 hours on a 3,125 calorie diet, on this admission her 24-hour glucose excretion never ex-

$2 \mathrm{We}$ are indebted to Dr. Peter Mueller, National Cancer Institute, who kindly performed these determinations. ceeded $150 \mathrm{~g}$ and acetonuria was absent. A subcutaneous fat biopsy was obtained and, after an uneventful postoperative course, she was again discharged on her previous diet.

Soon after discharge the patient noted a further decrease in glycosuria and in November 1959 her urine tests became negative for sugar. Concomitantly, menstruation reappeared and the severity of the acanthosis nigricans decreased. Blood sugars, both fasting and postprandial, were found to be within normal limits. An oral glucose tolerance test done at the University of Pennsylvania Hospital revealed normal carbohydrate tolerance with a tendency toward hypoglycemia during the third. to fifth hour of the test. Her response to a cortisone glucose tolerance test (19) was also normal and she was allowed an unrestricted diet. Over the following 10 months she gained $7 \mathrm{~kg}$ and was asymptomatic. She was readmitted to the Clinical Center in August 1960 for re-evaluation. Physical examination showed that she was entirely normal except for the acanthosis nigricans, which had cleared considerably. Her weight was $63 \mathrm{~kg}$. Urinalysis was normal and glycosuria was never observed. Fasting blood sugar was 60 , blood-urea-nitrogen 12 , and cholesterol $167 \mathrm{mg}$. per $100 \mathrm{ml}$; total protein 6.7 $\mathrm{g}$ per $100 \mathrm{ml}$ with $3 \mathrm{~g}$ albumin; protein-bound iodine 5.8 $\mu \mathrm{g}$ per $100 \mathrm{ml}$; 17 -ketosteroids 4.6 , and 17 -hydroxycorticosteroids $5.2 \mathrm{mg}$ per 24 hours. An oral glucose tolerance test (100 g glucose) gave the following results: fasting 60,1 hour 73, 2 hours 54, 3 hours 67,4 hours 42 , and 5 hours $60 \mathrm{mg}$ per $100 \mathrm{ml}$. At no time during the test were there any symptoms indicative of hypoglycemia. The results of an intravenous insulin tolerance test $(0.1$ $\mathrm{U}$ per $1 \mathrm{~g}$ ) are summarized in Table I. In contrast to the results in September 1959, $6 \mathrm{U}$ of insulin now produced severe hypoglycemia, indicating a normal insulin responsiveness. Previously, $200 \mathrm{U}$ i.v. had produced only a moderate fall in blood glucose levels. The half-time disappearance of a tracer dose of insulin- $\mathrm{I}^{131}$ given i.v. was 30 minutes, which is normal for non-insulin treated subjects (14). This rate is again markedly different from what it was in February 1959 during the peak of her insulin unresponsiveness (Figure 6). During this admission she was given $1 \mathrm{~g}$ sodium tolbutamide i.v. over a 30-minute period with the following results: blood sugar before infusion $62 \mathrm{mg}$ per $100 \mathrm{ml}$, at end of infusion 29, 30 minutes later 43,60 minutes later 51 , and 90 minutes later $55 \mathrm{mg}$ per $100 \mathrm{ml}$. She was discharged from the hospital on an unrestricted diet.

\section{RESULTS}

Plasma obtained 3 months after the patient's last known injection of insulin, when she was still diabetic, greatly stimulated glucose uptake by the isolated rat hemidiaphragm, as shown in Figure 1. Although $1 \mathrm{ml}$ of normal plasma also increased glucose uptake by diaphragm, the effect was small in comparison. On the basis of the insulin stand- 


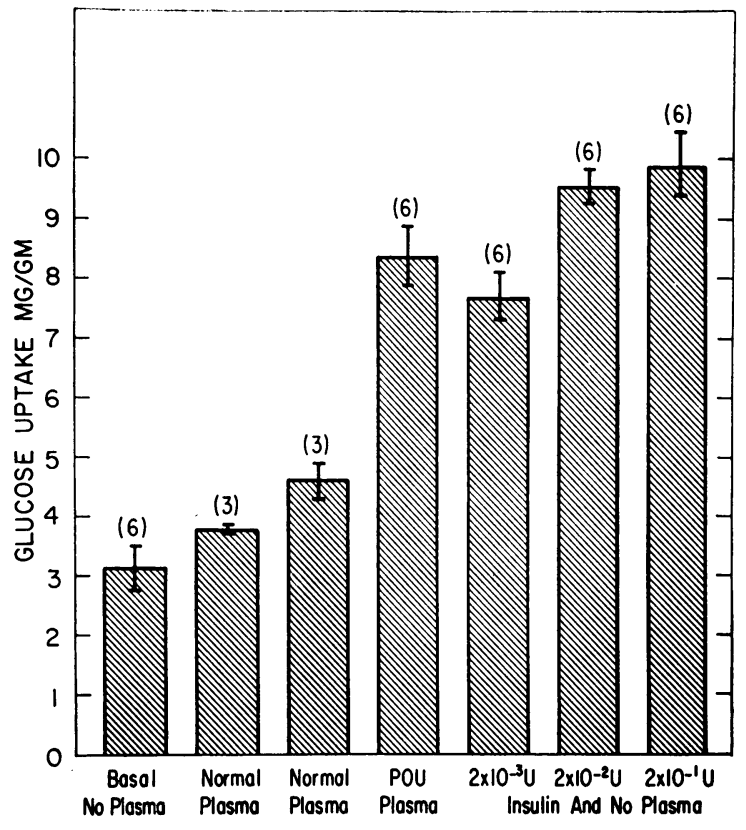

Fig. 1. EfFEct of PLASMa on GLUCOSE UPTAKe by ISOLATED RAT DIAPHRAGM.

ards used, her plasma contained at least $2 \mathrm{mU}$ of insulin per $\mathrm{ml}$. In this test system $20 \mathrm{mU}$ produced a maximal stimulation. In addition to augmenting glucose uptake, the patient's plasma stim-

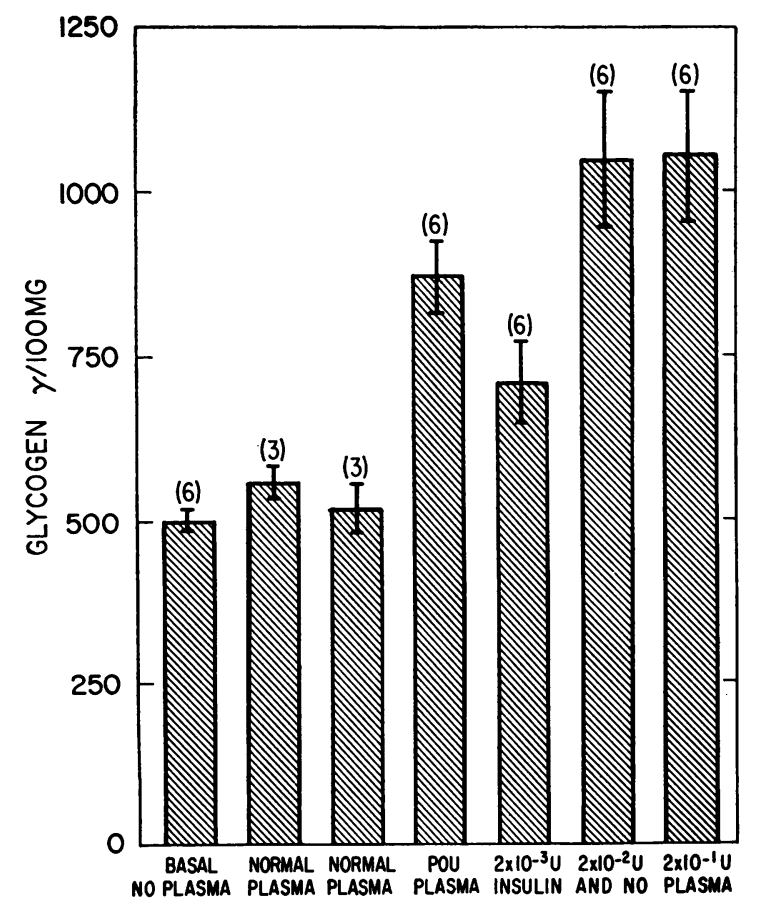

Fig. 2. Effect of plasma on the glycogen Deposition BY ISOLATED RAT DIAPHRAGM.

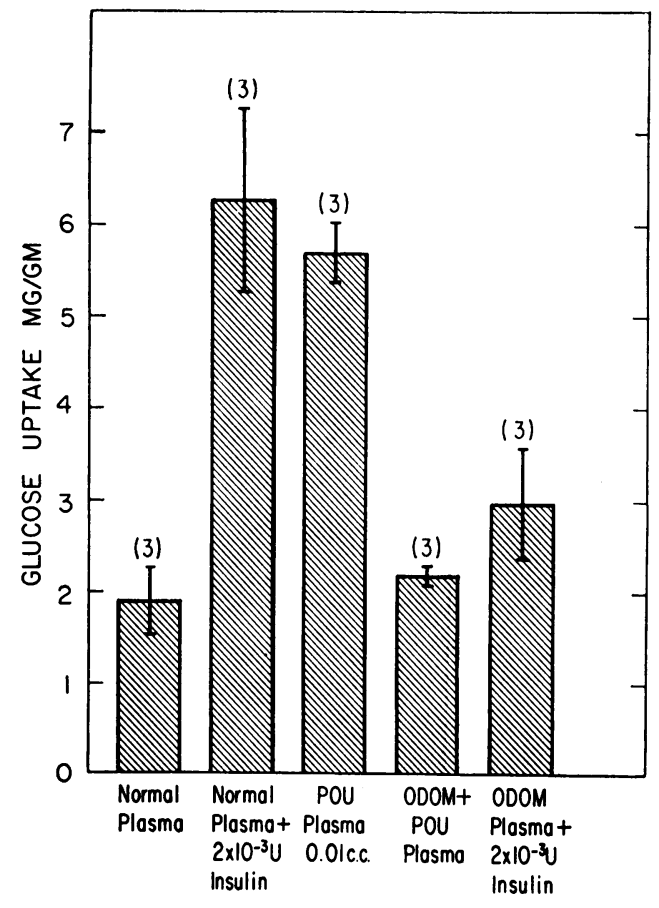

Fig. 3. InHIBItion of INSULIN EFFeCt of POU PLASMA BY INSULIN ANTAGONIST PLASMA.

ulated glycogen synthesis in the rat diaphragm while normal plasma did not differ from buffer alone (Figure 2). Again, in comparison with the insulin standards, the patient's plasma contained between 2 and $20 \mathrm{mU}$ of insulin per $\mathrm{ml}$. When the plasma was assayed by a specific immunological method it contained between 17 and $27 \mathrm{mU}$ of insulin per $\mathrm{ml}^{3}$

Figure 3 indicates that the glucose uptake stimulatory effect of the patient's plasma was abolished by the addition of plasma containing a circulating insulin antagonist. The addition of $2 \mathrm{mU}$ insulin to $1 \mathrm{ml}$ normal plasma increased the glucose uptake from 1.88 to $6.24 \mathrm{mg}$ per $\mathrm{g}$. In the presence of $0.01 \mathrm{ml}$ of the patient's plasma, the glucose uptake was $5.70 \mathrm{mg}$ per $\mathrm{g}$. The addition of $1 \mathrm{ml}$ of antagonist plasma to $0.01 \mathrm{ml}$ of the patient's plasma reduced the glucose uptake to the level found in the absence of any added insulin.

Although it would be unlikely that, 3 months after her last known injection of insulin, exogenous insulin would still be present, this possibility was tested by giving her a small amount of insulin- $\mathrm{I}^{131}$

${ }^{3}$ Dr. Gerold Grodsky, University of California Medical School, San Francisco, kindly performed these determinations. 

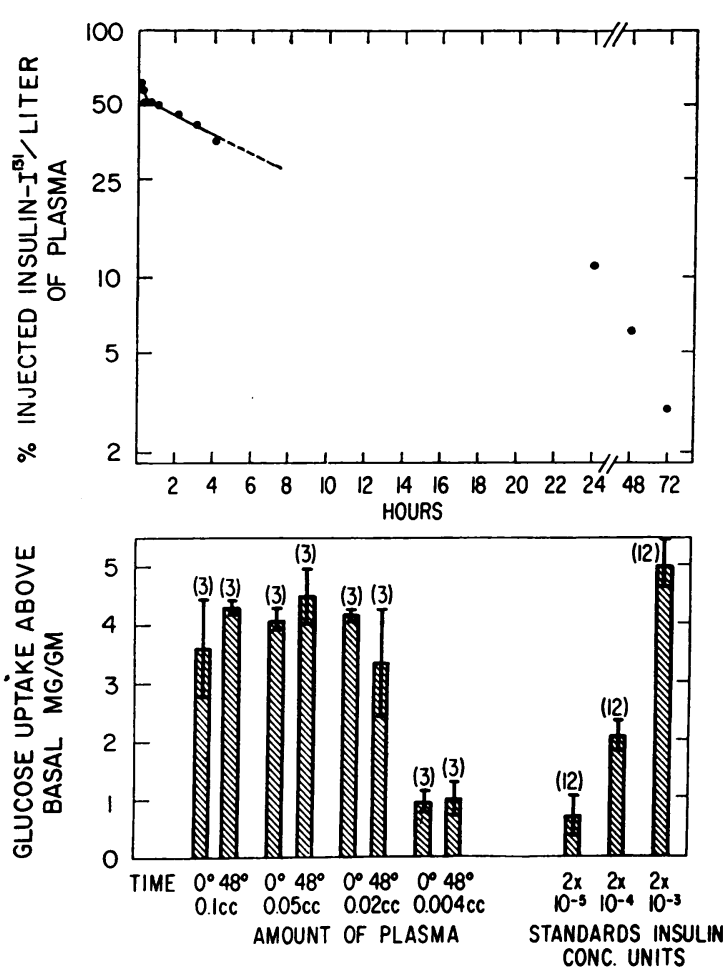

Fig. 4. Comparison of plasma insulin activity and RATE OF DISAPPEARANCE OF INJECTED TRACER INSULIN-I ${ }^{181}$.

and determining its rate of disappearance as well as the plasma insulin levels; 48 hours after injection, approximately 90 per cent of the insulin$\mathrm{I}^{131}$ had left the plasma (Figure 4). Despite the marked decrease in insulin- $\mathrm{I}^{131}$ the insulin content of plasma obtained just before the insulin- $\mathrm{I}^{131}$ injection and 48 hours later was essentially unchanged. This was true with various amounts of plasma, since decreasing the amount of plasma to $0.02 \mathrm{ml}$ did not appreciably diminish the stimulatory effect. It should be noted that the insulin standards employed in this study varied from $2 \times 10^{-5}$ to $2 \times 10^{-3} \mathrm{U}$ as compared with $2 \times 10^{-3}$ to $2 \times 10^{-1} \mathrm{U}$ in the two previous ones. From these studies it might appear that the insulin content of the plasma was greater than $20 \mathrm{mU}$ per $\mathrm{ml}$. This may not be the case, since it is known that dilution of plasma causes an apparent increase in its insulin activity (20).

In view of the large amounts of endogenous circulating insulin, it seemed feasible to attempt to fractionate the plasma to determine the location of insulin. Insulin-like activity has been reported in $\alpha-, \beta-$, and $\gamma$-globulin fractions, by various frac- tionation procedures (21-23). When stimulation of glucose uptake by rat diaphragm was used as a measure of insulin action, most of the activity appeared in the zone between the $\gamma$ - and $\beta$-globulins (Figure 5 ). In addition, there was a small peak of activity just behind albumin. When glycogen deposition was measured, insulin was found only in the region between the $\gamma$ - and $\beta$-globulins and extending into the $\beta$-globulins (Figure 6). The fractions just behind albumin, which stimulated glucose uptake, caused no increased glycogen deposition. Since glycogen deposition was a less sensitive parameter of insulin action (Figures 1 and 2), the amount of insulin in the fractions just behind albumin might not be sufficient to be detected by this method. It was also possible that these fractions contained other noninsulin substances which stimulated glucose uptake. It is known that several substances increase glucose uptake by rat diaphrgam, but insulin appears to be unique in its ability to augment glycogen content $(24,25)$. However, with insulin antagonist plasma, it was possible to abolish the glucose uptake stimulatory effect by the fractions that migrated just behind albumin, which suggests their identity with insulin.

Since this patient had received exogenous insulin injections for over 1 year, her plasma should

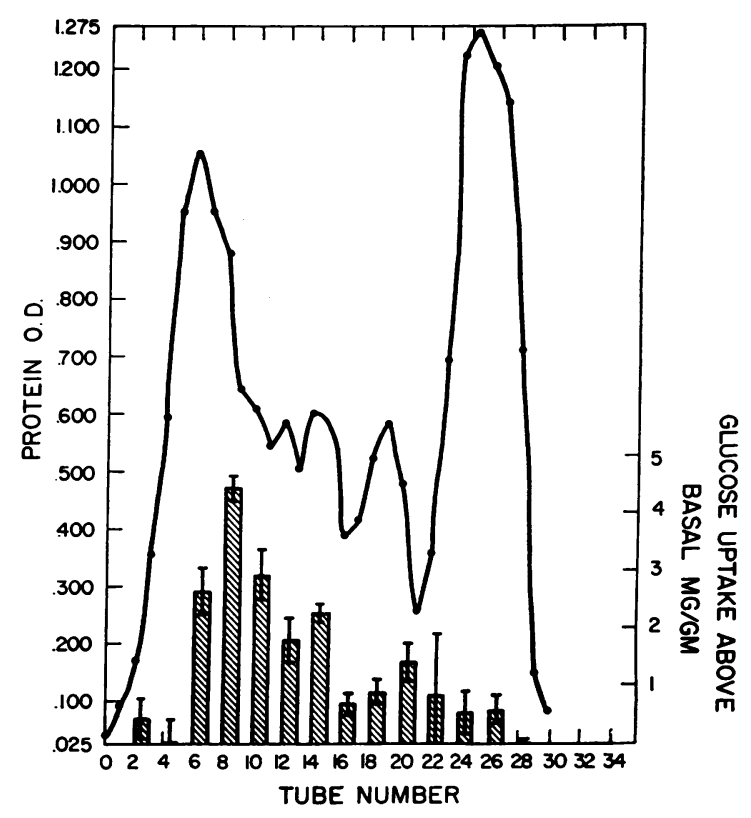

Fig. 5. EFFECT Óf PLASMa PROTEIN FRACtIONS ON GLUCOSE UPTAKE BY ISOL.ATED RAT DIAPHRAGM. 


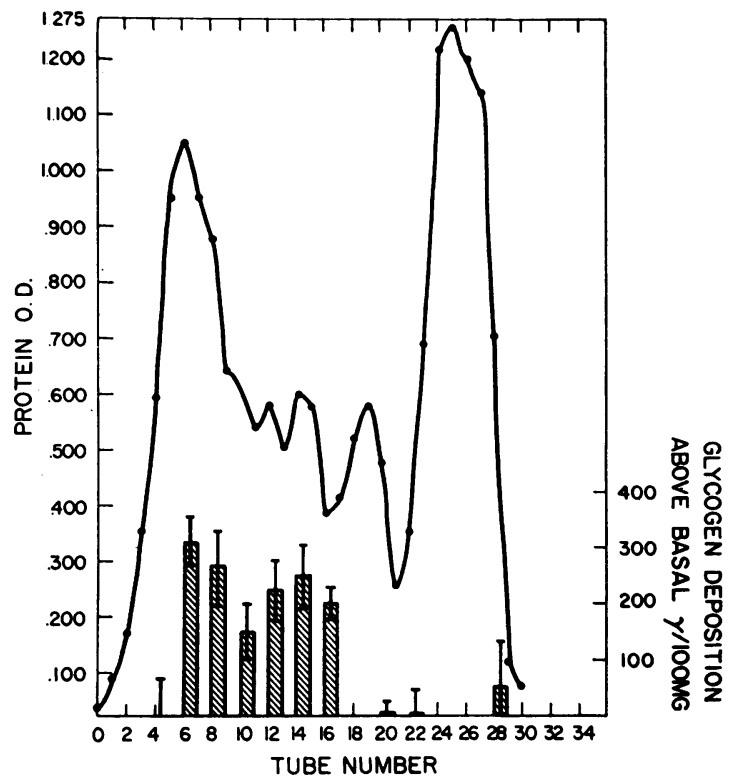

Fig. 6. EfFect of Plasma protein fractions on glycoGEN DEPOSITION BY ISOLATED RAT DIAPHRAGM.

contain insulin-binding antibody, as demonstrated by Berson and co-workers (14). This insulinbinding protein is located in the region between the $\gamma$ - and $\beta$-globulins and thus it is difficult to know whether the insulin activity in her plasma in this region represents insulin bound to the antibody or whether this is where endogenous insulin normally resides. When normal plasma with added insulin

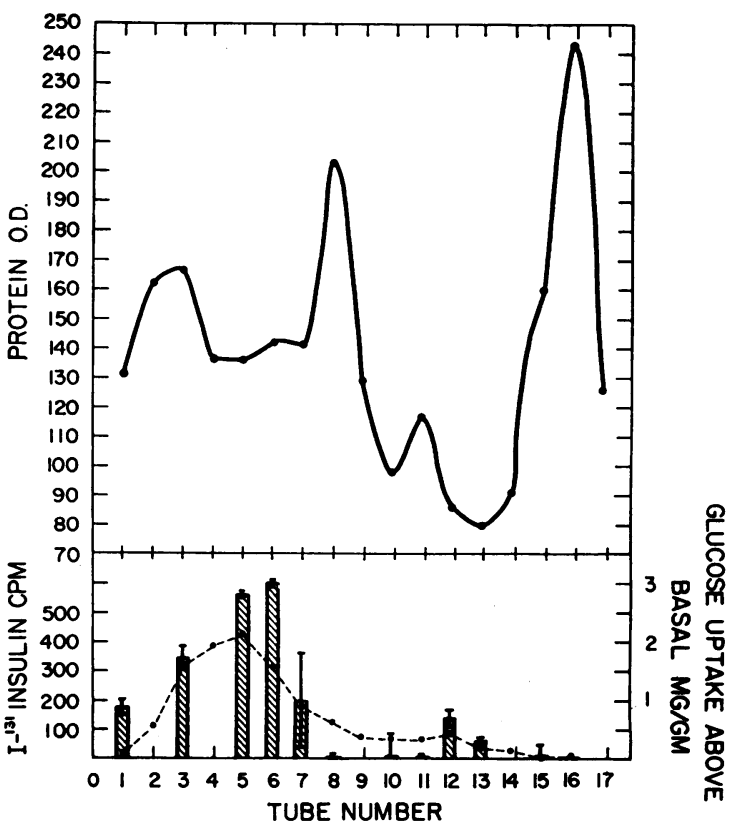

Fig. 7. Correlation between electrophoretic migraTION OF ADDED INSULIN-I ${ }^{131}$ AND INSULIN ACTIVITY OF POU PLASMA.

was fractionated in this manner, the insulin was recovered just behind albumin (14). It might be that the small amount of insulin in the patient's plasma migrating behind albumin was free insulin, while the bulk of the activty in the inter- $\beta-\gamma$ region was bound. A small amount $(20 \mu \mathrm{U}$ per

TABLE II

Effect of insulin on glucose uptake by human adipose tissue

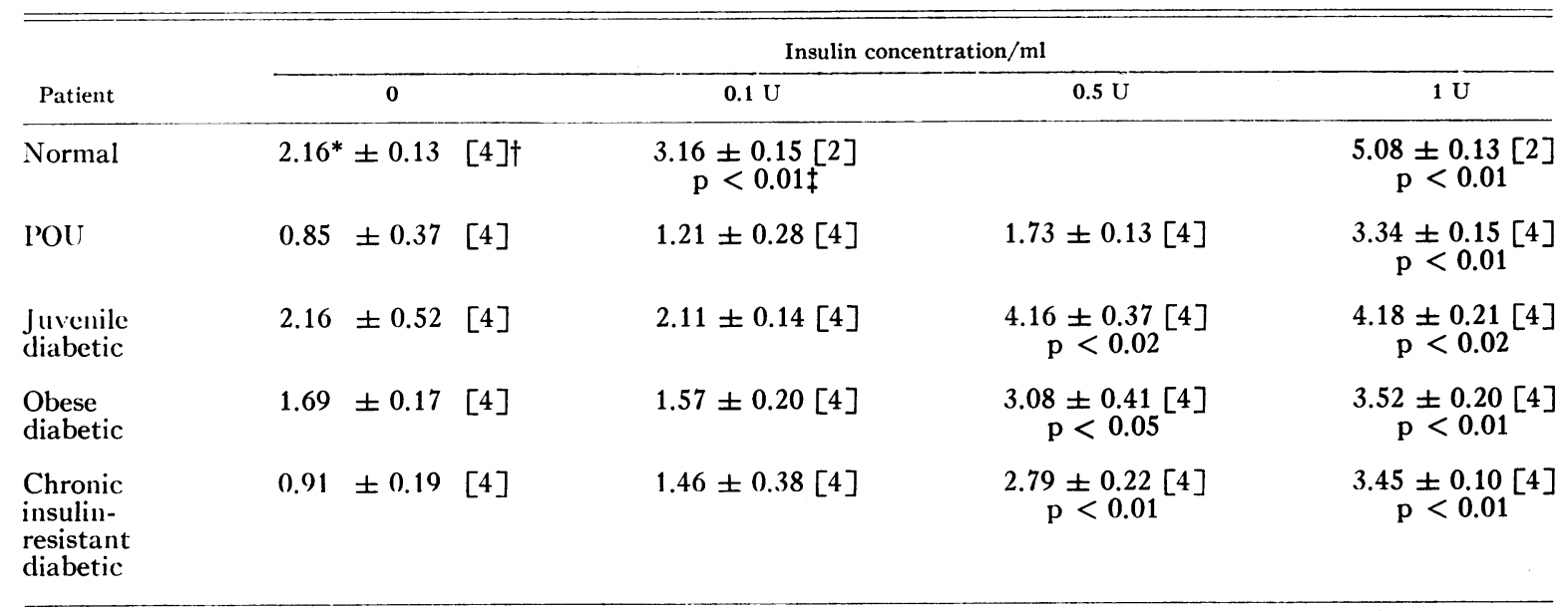

* Expressed as $\mathrm{mg} / \mathrm{g} \pm \mathrm{SE}$ of the mean.

$\dagger[]$, Number of determinations.

$\ddagger \mathrm{p}$ Value calculated on the comparison of the glucose uptake in absence and presence of insulin. Effect of insulin was not significant when no $p$ value is given. 
$\mathrm{ml})$ of insulin- $\mathrm{I}^{131}$ was added to her plasma before fractionation to determine whether the bound insulin- $\mathrm{I}^{131}$ would correspond to the area of endogenous insulin activity. Figure 7 demonstrates that most of the insulin- $\mathrm{I}^{131}$ was found between the $\beta$ - and $\gamma$-globulins in the same region with the bulk of the insulin activity. The amount of stimulation of glucose uptake was greatly in excess of the small amount of insulin- $\mathrm{I}^{131}$ added to the plasma prior to electrophoresis. In addition, there was a very small peak of insulin- ${ }^{131}$ just behind albumin, coinciding with the fractions that also appeared to contain some insulin.

The finding of large amounts of endogenous insulin in the patient's plasma in the presence of demonstrated unresponsiveness to its hypoglycemic effect certainly suggests absent or decreased tissue response to the hormone. The effect of insulin on her adipose tissue was tested in an attempt to obtain direct proof of this (Table II). When insulin was added to adipose tissue slices from a nondiabetic patient, there was a significant increase in the glucose uptake when $0.1 \mathrm{U}$ per $\mathrm{ml}$ was used and an even greater effect with $1 \mathrm{U}$ per $\mathrm{ml}$. However, in contrast, the adipose tissue from this patient showed no significant response to the addition of 0.1 or $0.5 \mathrm{U}$ per $\mathrm{ml}$, but did demonstrate an increased glucose uptake when $1 \mathrm{U}$ per $\mathrm{ml}$ was added. Adipose tissue from other representative diabetics, including one patient with chronic insulin resistance with circulating antagonist, also failed to respond to $0.1 \mathrm{U}$ insulin per $\mathrm{ml}$, but all gave significant increases when $0.5 \mathrm{U}$ was present. The insulin effect on leukocytes was also measured in an attempt to assess peripheral tissue responsiveness. The data in Table III indicate that the patient's leukocytes responded normally to the large amounts of insulin used. Even during an episode of diabetic acidosis, when

TABLE III

Effect of insulin on leukocyte glucose uptake*

\begin{tabular}{|c|c|c|}
\hline Source of leukocytes & Control & Insulin \\
\hline & \multicolumn{2}{|c|}{$m g$ glucose $/ 10^{10} \mathrm{WBC}$} \\
\hline $\begin{array}{l}\text { Patient pre- } R_{\mathbf{x}} \text { diabetic acidosis } \\
\text { Patient postrecovery acidosis } \\
\text { Normal } \\
\text { Normal }\end{array}$ & $\begin{array}{r}44 \\
154 \\
169 \\
142\end{array}$ & $\begin{array}{l}380 \\
431 \\
323 \\
360\end{array}$ \\
\hline
\end{tabular}

* $0.6 \mathrm{U}$ insulin $/ \mathrm{ml}$ incubation medium; incubations for 4

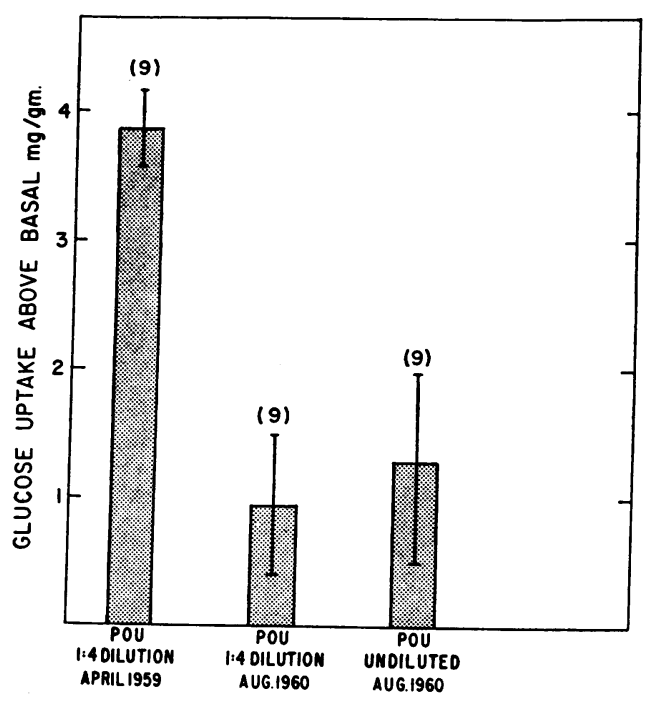

Fig. 8. Comparison of insulin activity in PLASMA DURING PERIOD OF INSULIN UNRESPONSIVENESS AND LATER DURING REMISSION.

her leukocytes removed considerably less glucose from the medium than did normal cells, the response to added insulin was unimpaired.

Whereas her plasma insulin levels were elevated during this period of unresponsiveness to insulin, at the time of her last admission, when the diabetes had remitted, her plasma insulin activity was normal (Figure 8).

During the initial Clinical Center admission, when she exhibited both diabetes and insulin unresponsiveness, her ability to oxidize glucose-1- $\mathrm{C}^{14}$ was assessed. Over a 5-hour period, 14.3 per cent of the tracer dose was recovered in $\mathrm{C}^{14} \mathrm{O}_{2}$. In similar studies, nondiabetics were found to oxidize an average of 37 per cent of the injected dose.

\section{DISCUSSION}

Clinically there can be little question that initially this patient was unresponsive to the hypoglycemic effects of insulin. Intravenous injection of as much as $200 \mathrm{U}$ of glucagon-free insulin failed to depress the blood sugar to normal levels and caused only a slightly greater fall than did $10 \mathrm{U}$ intravenously (Table I). Although she was maintained without insulin therapy, she had no diabetic symptoms despite glycosuria of $300 \mathrm{~g}$ per day on a 3,000 caloric diet. A diagnosis of diabetes certainly was justifiably based on her hyperglycemia and glycosuria. During her first admission to 
the Clinical Center she also had constant acetonuria and three episodes of mild diabetic acidosis. During the first two of these she was treated with massive doses of insulin while she recovered from the third episode with fluid therapy alone. The role of such fluids in her recovery is difficult to assess, since there appeared to be no dramatic effect on the levels of the free fatty acids. Such spontaneous recovery from diabetic acidosis does not coincide with our usual concept of this condition.

It is even more surprising that she was not always in diabetic acidosis in view of her extreme insulin unresponsiveness and massive glycosuria. Her constant ketonuria suggested that oxidation of fat was providing most of her energy requirements and that her carbohydrate utilization was severely impaired. She was given a tracer dose of glucose-1- $\mathrm{C}^{14}$ and its oxidation to $\mathrm{C}^{14} \mathrm{O}_{2}$ was measured to assess this. Over a 5-hour period 14.3 per cent of the injected dose appeared as $\mathrm{C}^{14} \mathrm{O}_{2}$, compared with 34 to 46 per cent when normal subjects were studied (17). However, when one corrects for the patient's enlarged glucose pool and urinary loss of glucose- $\mathrm{C}^{14}$ during the 5-hour test period, it is apparent that she was able to oxidize almost as much glucose as the normal, although at a much higher blood glucose concentration. This ability of the diabetic to utilize as much glucose as the nondiabetic, but at a substantially raised blood glucose concentration, has been previously demonstrated (26). At the present time it is difficult to reconcile the marked ketonuria with the concept that she was oxidizing almost as much glucose as the nondiabetic. Even more difficult to explain than the absence of constant diabetic acidosis is the absence of any of the usual symptoms of diabetes. It is conceivable that, although she appeared quite insulin-resistant, she was obtaining a small effect as a result of her high plasma insulin levels, and this was enough to prevent acidosis. During her second hospital admission she did not demonstrate acetonuria, and she had actually gained weight despite her impressive glycosuria. In retrospect, she may have been starting the remission which was complete several months after her discharge. This would be substantiated by the observation that her glycosuria had decreased from approximately $300 \mathrm{~g}$ during her first Clinical Center admission to an average of $100 \mathrm{~g}$ during her second admission, with no change in diet. Her spontaneous remission was quite unexpected and its cause is completely unknown. At present her glucose tolerance is normal, with a tendency toward hypoglycemia several hours after glucose ingestion. It is impossible to determine whether this hypoglycemia represents a manifestataion of "pre-diabetes" (27) or reflects the residual hyperfunction of her islets which was thought to be present during the period of insulin-unresponsive diabetes. Although temporary remissions have been frequently observed soon after the diagnosis and energetic treatment of diabetes mellitus in some juvenile patients, remission of such severe diabetes as the present patient had is most unusual (9). Since the genesis of her diabetes and insulin resistance is obscure, it is impossible to elaborate on its exodus.

In addition to undergoing remission, this patient differs from other cases of insulin resistance presumed to be due to tissue unresponsiveness (5-8) in that she had greatly increased amounts of endogenous insulin in her plasma. In the previous cases, plasma insulin was demonstrable only at a time when the patient was receiving injections of large amounts of insulin. This patient still had increased plasma insulin 3 months after her last known insulin injection. The fact that her plasma caused an in vitro increase in glycogen deposition of the isolated rat diaphragm as well as augmented glucose uptake strongly suggests that the activity was due to insulin. Although increased glucose uptake is probably not specific for insulin, this hormone is unique in its in vitro ability to stimulate glycogen deposition $(24,25)$. Salicylates and phenethylbiguanide also stimulate glucose uptake by diaphragm, but they both lead to a decrease in muscle glycogen. Further evidence for the identification of the activity as insulin is derived from the observation that its effect was abolished by the addition of plasma known to contain an insulin antagonist, presumably an antibody. This plasma had no effect on the basal uptake of glucose by the rat diaphragm but was capable of abolishing the increased glucose uptake produced by either insulin or the patient's plasma. In addition, assay of the patient's plasma by a specific immunological assay for insulin gave values in the same range as those obtained by bioassay. At a time when she was in remission her plasma insu- 
lin activity was normal. This is consistent with her demonstrated responsiveness to both insulin and tolbutamide (Orinase).

Although the patient's last known insulin injection was 3 months prior to these studies, it was still possible that the insulin detected in her plasma was a residue from the large amount of exogenous insulin she was given. The results of the study in which the rate of disappearance of a tracer dose of insulin- ${ }^{131}$ was followed make this unlikely. Whereas 90 per cent of the injected tracer had disappeared from the plasma at the end of 48 hours, the levels of plasma insulin were essentially the same as before the insulin- $\mathrm{I}^{131}$ was given. If the plasma insulin were exogenous in origin, one might expect the insulin concentration to decrease at the same rate as the insulin- $\mathrm{I}^{131}$ disappeared from the plasma. Since it did not, it indicates that pancreatic production of insulin must be continuing at a rate necessary to maintain the plasma level.

Another but less likely possibility is that the insulin- $\mathrm{I}^{131}$ did not label the entire insulin pool but was being metabolized at a rate different from that of a larger unlabeled insulin pool. Since this patient had demonstrable insulin antibody, one might consider the larger, unlabeled insulin pool as complexed with antibody, and the smaller, labeled pool as "free" insulin. It might thus be possible to maintain a constant plasma insulin level in association with a decreasing specific activity without implicating increased pancreatic insulin secretion if the rate of dissociation of insulin from antibody were considerably slower than the rate of disappearance of "free" insulin from the plasma. Against this possibility is the observation that the half-time disappearance of insulin- $\mathrm{I}^{131}$ was greatly prolonged, while in the nondiabetic, in the absence of insulin-binding antibody, it is about 30 minutes (14). This suggests that in this patient there was some, if not complete, mixing of insulin- $\mathrm{I}^{131}$ with the insulin-antibody pool. If the insulin- $\mathrm{I}^{131}$ were labeling only a smaller "free" insulin pool, one would expect its half-time of disappearance to approach that of the normal. The prolonged insulin- $\mathrm{I}^{131}$ disappearance in the insulin-treated subject has been presented as evidence for the existence of insulin-antibody complex and a reaction between injected insulin$\mathrm{I}^{131}$ and insulin antibody (14). It also seems unlikely that the insulin-antibody dissociation would be so slow that it would be a factor 3 months after the patient's last insulin injection.

Hyperglycemia is a known stimulus for pancreatic insulin production (28), and since this patient had continuous hyperglycemia her pancreas was being continually stimulated despite increased plasma insulin levels. This finding again points to an underlying failure of tissue response to insulin. In contrast to the slow rate of insulin- $\mathrm{I}^{131}$ disappearance when she was resistant, the hormone disappeared normally when she was again responsive to insulin. During this latter period she had not received insulin for well over a year, so that the shorter half-life might be due to the loss of insulin antibody which would retain injected insulin in her plasma.

In this case and several others (5-8), the cause of the insulin resistance was presumed to reside at the tissue level. It was not possible to detect any excess of insulin antagonists in this patient's plasma. The insulin that was present in her plasma appeared to have biologic activity in that it increased glucose uptake and glycogen deposition in the isolated rat diaphragm and produced hypoglycemia in fasted mice. ${ }^{4}$ When the response of her adipose tissue to insulin was studied, it was found less sensitive than adipose tissue from a normal person or other diabetics. This unresponsiveness was not complete, since in the presence of $1 \mathrm{U}$ per $\mathrm{ml}$ of incubation medium, her response was undiminished. While $0.5 \mathrm{U}$ per ml produced a significant increase in glucose uptake in all other patients studied, it failed to do so in the present patient. It is realized that these amounts of insulin are quite large and not in the physiologic range, making interpretation of the results more difficult. Nonetheless, there was a distinction between this patient's adipose tissue and that obtained from other diabetics, including one with chronic insulin resistance. However, the patient's leukocytes appeared to be as insulin-responsive as normal leukocytes when glucose uptake was measured. Since the amounts of insulin used in these experiments were also large, interpretation of the results in terms of in rivo responsiveness to insulin is difficult. It is of interest that except when the patient was in diabetic

${ }^{t}$ Dr. Frederick Goetz, University of Minnesota, kindly performed these studies. 
acidosis, her leukocytes removed as much glucose from the incubation medium as do normal white blood cells. In the presence of a clecreased tissue responsiveness to insulin, the greatly elevated plasma levels may have been sufficient to prevent severe diabetic acidosis. Although conclusive demonstration is lacking, the cause of her insulin resistance seems to be due to a decreased tissue response to this hormone.

By rat hemidiaphragm assay, her plasma contained between 2 and $20 \mathrm{mU}$ of insulin per $\mathrm{ml}$. while the normal level by a more specific immunoassay was approximately $0.02 \mathrm{mU}$ per $\mathrm{ml}$ (29). Her plasma contained $10 \mathrm{mU}$ per $\mathrm{ml}$ assayed by its hypoglycemic action in the fasted mouse. ${ }^{4}$ Fractionation of the plasma by electrophoresis indicated that most of the insulin was present in the area between the $\beta$ - and $\gamma$-globulins, while a small part migrated just behind albumin. Insulin was found in the $\beta$-globulins in another patient with insulin resistance in whose plasma exogenous insulin was detectable (6). In normal plasma, insulin has been reported to be located in the $\gamma$-, $\beta$ - and $\alpha$-globulins (21-23). Since insulin-binding protein also migrates in the area between $\gamma$ - and $\beta$-globulin, and since this patient had received prior exogenous insulin, it is impossible to decide whether the insulin in the inter- $\gamma-\beta$ zone was complexed to the insulin-binding protein or not. The former possibility might seem more reasonable, since there was also a small amount of insulin just behind albumin where "free" insulin is known to migrate (14).

\section{SUM MARY}

The case of an 18 year old Negro female diabetic with severe insulin unresponsiveness, presumably as a result of decreased tissue responsiveness, is presented. Over a period of 18 months there was a complete remission of both her insulin resistance and her diabetes. Unique features of the case include the presence of large amounts of circulating endogenous insulin which appeared to have full physiologic activity in the isolated rat hemidiaphragm and the fasted mouse at a time when she was unresponsive to the hormone. Its identification as insulin was based on its ability to increase in vitro muscle glycogen deposition as well as glucose uptake by rat diaphragm. In ad- clition, its effect could be abolished by the addition of insulin antagonist plasma. While 90 per cent of an injected tracer dose of insulin- ${ }^{131}$ disappeared from the plasma in 48 hours, there was no change in the plasma insulin level during this time. Fractionation of the plasma indicated that most of the insulin activity resided in the inter- $\gamma-\beta$-globulin zone, although there was also a small amount migrating just behind albumin. Adipose tissue obtained from the patient demonstrated no increase in glucose uptake in the presence of 0.1 and $0.5 \mathrm{U}$ insulin per ml, while normal adipose tissue responded to the former and adipose tissue from other diabetics responded to the latter concentration. In the presence of $1 \mathrm{U}$ per $\mathrm{ml}$ insulin, her adipose tissue demonstrated a normal response.

Although the cause of her insulin resistance was thought to be due to decreased tissue responsiveness, the mechanism of this as well as her subsequent complete remission, is unknown.

\section{REFERENCES}

1. Axclrod, A. R., Lobe, S., Orten, J. M., and Myers, (i. B. Insulin resistance. Ann. intern. Med. 1947, 27, 555 .

2. Berson, S. A., and Yalow, R. S. Kinetics of reaction between insulin and insulin-binding antibody (abstract). J. clin. Invest. 1957, 36, 873.

3. Field, J. B. Studies on the circulating insulin inhibitor found in some diabetic patients exhibiting chronic insulin resistance. J. clin. Invest. 1959, $38,551$.

4. Oakley, W., Field, J. B., Sowton, G. E., Rigby, B., and Cunliffe, A. C. Action of prednisone in insulin-resistant diabetes. Brit. med. J. 1958, 1, 1601.

5. Presland, J. R., and Todd, C. M. Investigation of prolonged insulin resistance in case of diabetes mellitus. Quart. J. Med. 1956, 25, 275.

6. Downie, E. Diabetes mellitus and clinical research: Study of insulin resistance. Ann. intern. Med. 1957, 46, 126.

7. Davidson, J. K., III, and Eddleman, E. E., Jr. Insulin resistance: Review of literature and report of case associated with carcinoma of pancreas. Arch. intern. Med. 1950, 86, 727.

8. Leonards, J. R., and Martin, F. I. R. Insulin insensitivity; a variant of insulin resistance. New Engl. J. Med. 1959, 261, 68.

9. Stutman, L. J., and Hayes, J. D. Severe diabetes with remission: Report of a case. Diabetes 1959, 8, 189.

10. Seifter, S., Dayton, S., Novic, B., and Muntwygler, I. The estimation of glycogen with the anthrone reagent. Arch. Biochem. 1950, 25, 191. 
11. Kunkel, H. G., and Slater, R. J. Zone electrophoresis in a starch supporting medium. Proc. Soc. exp. Biol. (N.Y.) 1952, 80, 42.

12. Lowry, O. H., Rosebrough, N. J., Farr, A. L., and Randall, R. J. Protein measurement with the Folin phenol reagent. J. biol. Chem. 1951, 193, 265.

13. Mortimore, G. E., Tietze, F., and Stetten, D., Jr. Metabolism of insulin- $\mathrm{I}^{131}$; Studies in isolated, perfused rat liver and hind-limb preparations. Diabetes 1959, 8, 307.

14. Berson, S. A., Yalow, R. S., Bauman, A., Rothschild, M. A., and Newerly, K. Insulin- $\mathrm{I}^{131}$ metabolism in human subjects: Demonstration of insulin binding globulin in the circulation of insulin treated subjects. J. clin. Invest. 1956, 35, 170.

15. Martin, D. B., Renold, A. E., and Dagenais, Y. M. An assay for insulin-like activity using rat adipose tissue. Lancet 2, 1958, 76.

16. Weinberg, A. N. In vitro effects of insulin on carbohydrate metabolism of normal and diabetic leucocytes. In preparation.

17. Segal, S., Berman, M., and Blair, A. The metabolism of variously $\mathrm{C}^{14}$-labeled glucose in man and an estimation of the extent of glucose metabolism by the hexose monophosphate pathway. J. clin. Invest. 1961, 40, 1263.

18. Field, J. B. Unpublished observations.

19. Fajans, S. S., and Conn, J. W. An approach to the prediction of diabetes mellitus by modification of the glucose tolerance test with cortisone. Diabetes 1954, 3, 296.
20. Willebrands, A. F., van der Geld, H., and Groen, J. Determination of serum insulin using the isolated rat diaphragm; the effect of serum dilution. Diabetes $1958,7,119$.

21. Beigelman, P. M. Insulin-like activity of serum protein fractions. Diabetes 1958, 7, 365.

22. Taylor, K. W. The effect of human serum protein fractions on the glucose uptake of the isolated rat diaphragm. Biochem. J. 1958, 69, 59P.

23. Antoniades, H. Separation of human plasma protein concentrate with insulin activity. Science 1958, 127, 593.

24. Randle, P. J., and Smith, G. H. Regulation of glucose uptake by muscle. I. The effects of insulin, anaerobiosis and cell poisons on the uptake of glucose and release of potassium by isolated rat diaphragm. Biochem. J. 1958, 70, 490.

25. Segal, S., Blair, A., and Weinberg, A. In vitro effects of salicylate on carbohydrate metabolism. Metabolism 1960, 9, 1033.

26. Soskin, S., and Levine, R. A relationship between the blood sugar level and the rate of sugar utilization, affecting theories of diabetes. Amer. J. Physiol. 1937, 120, 761.

27. Seltzer, H. S., Fajans, S. S., and Conn, J. W. Spontaneous hypoglycemia as an early manifestation of diabetes mellitus. Diabetes 1956, 5, 437.

28. Metz, R. The effect of blood glucose concentration on insulin output. Diabetes 1960, 9, 89.

29. Yalow, R. S., and Berson, S. A. Immunoassay of endogenous plasma insulin in man. J. clin. Invest. 1960, 39, 1157. 